\title{
Perbandingan R-Baux Score dengan BOBI Score sebagai Prediktor Mortalitas Pasien Luka Bakar di RSUP Dr. M. Djamil Padang
}

\author{
Azdiana Fitri, ${ }^{1}$ Deddy Saputra, ${ }^{2}$ Andani Eka Putra ${ }^{3}$ \\ ${ }^{1}$ Pendidikan Dokter Spesialis Bedah Umum Fakultas Kedokteran Universitas Andalas Padang, Indonesia \\ ${ }^{2}$ Bagian Bedah Divisi Bedah Plastik dan Rekonstruksi Fakultas Kedokteran Universitas Andalas/RSUP Dr. M. \\ Djamil Padang, Indonesia, ${ }^{3}$ Bagian Mikrobiologi Fakultas Kedokteran Andalas Padang, Indonesia
}

\begin{abstract}
Abstrak
Sistem skoring pada luka bakar sangat dibutuhkan sebagai nilai objektif untuk prediktif mortalitas. Belum ada sistem skoring objektif terbaik sebagai prediktif mortalitas luka bakar. Penelitian ini bertujuan membandingkan akurasi $R$ - Bauxdan BOBI score dalam memprediksi mortalitas pasien luka bakar di RSUP Dr. M. Djamil, Padang. Penelitian dilakukan Januari 2013 sampai September 2017, menggunakan desain studi retrospektif pada pasien luka bakar yang dirawat di Unit Luka Bakar RSUP Dr. M. Djamil, Padang. Data diolah menggunakan uji diagnostik, uji Kappa, dan uji regresi logistik terhadap variabelnya. Jumlah sampel adalah 394 sampel. Sampel terbanyak lakilaki, rerata usia 28,3 $\pm 18,3$ tahun, penyebab luka bakar terbanyak api, rerata total body surface area (TBSA) 26,1\%, trauma inhalasi 51\% dan angka mortalitas 26,4\%. Uji sensitivitas BOBI score dibanding dengan R-Baux score adalah 96,83\%: 92,89\% dengan koefisien Kappa sebesar 0,50. Analisis regresi logistik menunjukkan variabel umur, TBSA, dan trauma inhalasi saling berhubungan pada R-Baux score. Uji diagnostik BOBI score lebih baik dibanding dengan $R$-Bauxscore dan nilai koefisien Kappa menunjukkan kesesuaian hasil dengan BOBI score. BOBI score lebih baik sebagai prediktor mortalitas di RSUP Dr. M. Djamil Padang dibanding dengan R-Bauxscore karena menunjukkan akurasi lebih baik setelah diuji dengan nilai real.
\end{abstract}

Kata kunci: BOBI score, luka bakar, mortalitas, r-baux score

\section{Comparison between R-Baux Score and BOBI Score as a Predictor of Burn Mortality in Dr. M. Djamil Hospital Padang}

\begin{abstract}
Burns are the type of trauma with high morbidity and mortality. No best objective scoring system is currently available to predict mortality in burn cases. This study aimed to compare the accuracy of R-Baux and BOBI scores in predicting mortality among burn patients in Dr. M. Djamil Hospital, Padang. This was a retrospective study on burn patients treated in burn unit of this hospital from January 2013 to September 2017. Assessments were performed on diagnostic test, kappa tests, and logistic regression test. Out of 394 samples enrolled men were more prominent, while the mean age of these patients was $28.3 \pm 18.3$ years old with fire as the most frequent cause. The, mean TBSA and inhalation injury were $26.1 \%$ and $51 \%$, respectively, with an overall mortality of 26.4\%. The sensitivity test performed to compare BOBI and R-Baux scores revealed the result of 96.83\%: $92.89 \%$ with 0.50 coefficient's value of Kappa. Logistic regression test showed that age, TBSA, dan inhalation injury significantly correlated with R-Baux score, Diagnostic test result of BOBI score was better than R-Baux score and the coefficient's value of Kappa showed a matched result with BOBI score with medium strength. BOBI score shows better accuracy as the mortality predictor of burn cases in Dr. M. Djamil Hospital Padang.
\end{abstract}

Key words: BOBI score, burns, mortality, r-baux score

Korespondensi: Azdiana Fitri, dr., Program Pendidikan Dokter Spesialis Bedah Umum Universitas Andalas/RSUP Dr. M. Djamil Padang. Jalan Perintis Kemerdekaan, Sawahan Tim, Kota Padang, Sumatera Barat 25171, Email: azfitri010110@gmail.com 


\section{Pendahuluan}

Luka bakar merupakan bentuk kerusakan atau kehilangan jaringan yang disebabkan oleh kontak dengan sumber panas seperti api, air panas, bahan kimia, listrik dan radiasi atau suhu yang sangat rendah. ${ }^{1}$

Sistem skoring pada luka bakar sangat dibutuhkan sebagai nilai objektif untuk prediktif kematian. Sampai saat ini belum ada sistem skoring objektif yang terbaik sebagai prediktif kematian pada luka bakar. ${ }^{2}$ Salah satu yang dibahas pada penelitian ini adalah sistem skoring R-Baux score dan Belgian Outcome in Burn Injury (BOBI) score karena dinilai lebih sederhana digunakan pada kejadian luka bakar akut dan juga mereka menggunakan parameter yang sama, yaitu usia total body surface area (TBSA) dan ada tidaknya trauma inhalasi, tetapi berbeda di poin skor. ${ }^{2-4}$

$R$-Baux score diaplikasikan secara luas di Amerika Serikat, diperkenalkan oleh Osler dkk. karena penggunaannya yang sederhana dengan formula Usia + TBSA + (17XR), R=1 jika ada trauma inhalasi dan $\mathrm{R}=0$ jika tanpa trauma inhalasi. Risiko mortalitas bervariasi dari $0-100 \% .{ }^{2}$ BOBI score mulai dikembangkan pada tahun 2009 (Tabel 1). ${ }^{6,7}$ Penelitian ini bertujuan membandingkan sistem skor mana yang paling baik yang akan digunakan pada pasien luka bakar akut di RSUP Dr. M. Djamil Padang.

\section{Metode}

Penelitian menggunakan desain studi retrosfektif pada semua pasien luka bakar yang pernah dirawat di Unit Luka Bakar RSUP Dr. M. Djamil Padang sebagai subjek penelitian, mulai bulan Januari 2013 sampai September 2017 dengan total populasi sebanyak 434 orang. Penelitian dilakukan padabulan Oktober sampai November
2017. Sampel adalah total sampling yang memenuhi kriteria inklusi yaitu semua pasien luka bakar semua usia dan semua penyebab, serta kriteria eksklusi, yaitu luka bakar yang disertai dengan trauma penyerta lain, catatan medik yang tidak lengkap, atau disertai penyakit penyerta sebelumnya. Data akan diolah dan dianalisis dengan menguji diagnostik $R$ - Baux dan BOBI score dengan uji sensitivitas, spesifisitas, nilai duga positif dan nilai duga negatif, dan membandingkan dengan nilai real, menguji nilai kesesuaian dengan uji Kappa, serta menguji regresi logistik dengan menganalisis variabelvariabelnya.

\section{Hasil}

Total pasien yang dijadikan sampel penelitian adalah sampel memenuhi kriteria inklusi dan tidak termasuk eksklusi yang berjumlah 394 orang. Data variabel yang dilihat adalah usia pasien, TBSA, dan ada tidaknya trauma inhalasi. Lalu dilihat juga variabel lain seperti penyebab luka bakar, lama rawatan serta outcome meninggal atau hidup. Seluruh sampel diberikan skor dengan nilai prediktor mortalitas $R$-Baux dan BOBI score.

Pada penelitian ini diperoleh sampel jenis kelamin laki-laki sebanyak 262 orang $(66,5 \%)$ dan perempuan sebanyak 132 orang $(33,5 \%)$, dengan perbandingan 1,98:1. Sampel terbanyak adalah di kelompok usia $<50$ tahun sebanyak 336 pasien $(85,3 \%)$ dengan rerata usia adalah $28,3 \pm 18,3$ tahun. Penyebab luka bakar terbanyak adalah luka bakar karena api sebanyak 222 sampel $(56,3 \%)$ dan disertai trauma inhalasi sebanyak 201 sampel (51\%). Total body surface area terbanyak yang dirawat adalah kelompok sampel dengan TBSA $<20 \%$ sebanyak 178 sampel $(45,20 \%)$, dengan rerata TBSA $26,1 \%$. Rerata nilai prediktor mortalitas R-Baux score

Tabel 1 BOBI Score

\begin{tabular}{lccccc}
\hline & $\mathbf{0}$ & $\mathbf{1}$ & $\mathbf{2}$ & $\mathbf{3}$ & $\mathbf{4}$ \\
\hline Usia (tahun) & $<50$ & $50-64$ & $65-79$ & $>80$ & \\
TBSA (\%) & $<20$ & $20-39$ & $40-59$ & $60-79$ & $>80$ \\
Trauma inhalasi & Tidak & & & Ya &
\end{tabular}

\begin{tabular}{lccccccccccc} 
& \multicolumn{11}{c}{ Skor Total } \\
& $\mathbf{0}$ & $\mathbf{1}$ & $\mathbf{2}$ & $\mathbf{3}$ & $\mathbf{4}$ & $\mathbf{5}$ & $\mathbf{6}$ & $\mathbf{7}$ & $\mathbf{8}$ & $\mathbf{9}$ & $\mathbf{1 0}$ \\
Prediksi mortalitas (\%) & 0,1 & 1,5 & 5 & 10 & 20 & 30 & 50 & 75 & 85 & 95 & 99 \\
\hline
\end{tabular}


Tabel 2 Distribusi Frekuensi Karakteristik Responden yang Meninggal

\begin{tabular}{|c|c|c|}
\hline Karakteristik & $\mathbf{n}$ & $\%$ \\
\hline \multicolumn{3}{|l|}{ Usia (tahun) } \\
\hline$<50$ & 86 & 82,7 \\
\hline$\geq 50$ & 18 & 17,3 \\
\hline \multicolumn{3}{|l|}{ Jenis kelamin } \\
\hline Laki-laki & 61 & 58,7 \\
\hline Perempuan & 43 & 41,3 \\
\hline \multicolumn{3}{|l|}{ Penyebab } \\
\hline Api & 82 & 78,8 \\
\hline Listrik & 5 & 4,8 \\
\hline Air panas & 14 & 13,5 \\
\hline Minyak panas & 2 & 1,9 \\
\hline Lain-lain & 1 & 1,0 \\
\hline \multicolumn{3}{|l|}{ TBSA (\%) } \\
\hline$<20$ & 5 & 4,8 \\
\hline $20-39$ & 33 & 31,7 \\
\hline $40-59$ & 33 & 31,7 \\
\hline $60-79$ & 24 & 23,1 \\
\hline$>80$ & 9 & 8,6 \\
\hline Traumainhalasi & 96 & 92,3 \\
\hline R-Baux score & - & - \\
\hline BOBI score & - & - \\
\hline Lama rawatan & - & - \\
\hline
\end{tabular}

Keterangan: Mean= 30,93 adalah 63,11 dengan median 58,50 dan rerata nilai prediktor mortalitas BOBI score adalah 2,57 dengan median 3,00 . Rerata lama rawatan adalah $14,17 \pm 13,83$ hari. Angka mortalitas sebanyak $26,4 \%$ atau 104 sampel.

Sampel yang meninggal laki-laki lebih banyak apabila dibanding dengan perempuan, yaitu 61 sampel $(58,7 \%)$ untuk laki-laki dan 43 sampel $(41,3 \%)$ untuk perempuan. Sampel terbanyak yang meninggal adalah di kelompok usia $<50$ tahun sebanyak 86 sampel $(58,6 \%)$. Penyebab luka bakar terbanyak pada sampel yang meninggal adalah luka bakar karena api sebanyak 82 sampel $(78,9 \%)$, disertai dengan trauma inhalasi sebanyak 96 sampel $(92,3 \%)$. Total body surface area terbanyak pada sampel yang meninggal adalah kelompok sampel dengan TBSA $20-59 \%$, yaitu 66 sampel $(63,5 \%)$, dengan rerata TBSA 47,9\%. Rerata nilai prediktor mortalitas $R$-Baux score adalah 94,5 dan rerata nilai prediktor mortalitas BOBI score adalah 4,9. Rerata lama rawatan sampel meninggal adalah 8,3 hari. Gambaran distribusi frekuensi data responden yang meninggal dari penelitian ini dapat dilihat pada Tabel 2 .

Dari total 59 mortalitas yang diprediksi berdasar atas prediktor luka bakar R-Baux score, diperoleh 104 mortalitas terobservasi. Nilai prediktor di atas 130 diperoleh mortalitas 100\%. Dari total 64 mortalitas yang diprediksi berdasar atas prediktor luka bakar BOBI score

Tabel 3 Prediksi Mortalitas berdasar atas R-Baux Score

\begin{tabular}{ccccc}
\hline Skor & $\begin{array}{c}\text { Prediksi } \\
\text { Motalitas (\%) }\end{array}$ & $\begin{array}{c}\text { Total } \\
\text { (n=394) }\end{array}$ & $\begin{array}{c}\text { Mortalitas } \\
\text { Terobservasi } \\
\text { (n=104) }\end{array}$ & $\begin{array}{c}\text { Mortalitas } \\
\text { diprediksi } \\
\text { (n=59) }\end{array}$ \\
\hline $1-9$ & 0,1 & 6 & $0(0 \%)$ & 0 \\
$10-19$ & 0,2 & 20 & $1(0,05 \%)$ & 0 \\
$20-29$ & 0,3 & 35 & $2(5,7 \%)$ & 1 \\
$30-39$ & 0,4 & 38 & $2(5,3 \%)$ & 1 \\
$40-49$ & 0,5 & 65 & $4(6,2 \%)$ & 1 \\
$50-59$ & 1 & 35 & $5(14,3 \%)$ & 1 \\
$60-69$ & $2-3$ & 45 & $8(17,8 \%)$ & 2 \\
$70-79$ & $4-5$ & 40 & $14(35 \%)$ & 2 \\
$80-89$ & $10-15$ & 26 & $8(30,8 \%)$ & 6 \\
$90-99$ & $20-25$ & 24 & $12(50 \%)$ & 8 \\
$100-109$ & $30-45$ & 17 & $11(64,7 \%)$ & 11 \\
$110-119$ & $45-60$ & 18 & $14(77,9 \%)$ & 9 \\
$120-129$ & $65-75$ & 12 & $10(83,3 \%)$ & 5 \\
$130-139$ & $80-90$ & 5 & $5(100 \%)$ & 6 \\
$140-149$ & $90-95$ & 6 & $6(100 \%)$ & 1 \\
$150-159$ & $95-97$ & 1 & $1(100 \%)$ & 0 \\
$160-169$ & $98-99$ & 1 & $1(100 \%)$ & \\
$170-200$ & $99-00$ & 0 & $0(100 \%)$ & \\
\hline
\end{tabular}


Azdiana Fitri dkk.: Perbandingan R-Baux Score dengan BOBI Score sebagai Prediktor Mortalitas Pasien Luka Bakar

Tabel 4 Prediksi mortalitas berdasarkan BOBI Score

\begin{tabular}{ccccc}
\hline Skor & $\begin{array}{c}\text { Prediksi Motalitas } \\
\text { (\%) }\end{array}$ & $\begin{array}{c}\text { Total } \\
(\mathbf{n = 3 9 4 )}\end{array}$ & $\begin{array}{c}\text { Mortalitas terobservasi } \\
(\mathbf{n = 1 0 4 )}\end{array}$ & $\begin{array}{c}\text { Mortalitas } \\
\text { diprediksi } \\
(\mathbf{n = 6 4 )}\end{array}$ \\
\hline 0 & 0,1 & 120 & $2(1,7 \%)$ & 1 \\
$\mathbf{1}$ & 1,5 & 62 & $4(6,4 \%)$ & 1 \\
$\mathbf{2}$ & 5 & 7 & $0(0 \%)$ & 1 \\
$\mathbf{3}$ & 10 & 35 & $4(11,4 \%)$ & 4 \\
$\mathbf{4}$ & 20 & 77 & $24(31,2 \%)$ & 16 \\
$\mathbf{5}$ & 30 & 51 & $33(64,7 \%)$ & 16 \\
$\mathbf{6}$ & 50 & 28 & $23(82,1 \%)$ & 14 \\
$\mathbf{7}$ & 75 & 12 & $12(100 \%)$ & 2 \\
$\mathbf{8}$ & 85 & 2 & $2(100 \%)$ & 0 \\
$\mathbf{9}$ & 95 & 0 & $0(100 \%)$ & 0 \\
$\mathbf{1 0}$ & 99 & 0 & $0(100 \%)$ & \\
\hline
\end{tabular}

Tabel 5 Akurasi R-Baux dan BOBI Score dibandingkan dengan Nilai Real

\begin{tabular}{lccccc}
\hline Score & $\begin{array}{c}\text { Cut-off } \\
\text { Point }\end{array}$ & Sensitivitas (\%) & $\begin{array}{c}\text { Spesifisitas } \\
\text { (\%) }\end{array}$ & $\begin{array}{c}\text { Nilai Duga } \\
\text { Positif (\%) }\end{array}$ & $\begin{array}{c}\text { Nilai Duga } \\
\text { Negatif (\%) }\end{array}$ \\
\cline { 2 - 6 } R-Baux & 58 & 92,89 & 45,69 & 63,10 & 86,54 \\
& 63 & 92,20 & 49,43 & 69,31 & 83,65 \\
& 94 & 85,17 & 74,03 & 93,10 & 54,81 \\
BOBI & 3 & 96,83 & 47,80 & 63,10 & 94,23 \\
& 4 & 95,54 & 49,33 & 73,79 & 88,10 \\
\hline
\end{tabular}

diperoleh 104 mortalitas terobservasi. Pada penelitian ini nilai prediktor BOBI score di atas 7 diperoleh mortalitas 100\%. Prediksi mortalitas berdasar atas nilai prediktor mortalitas $R$-Baux score dan BOBI score pada penelitian ini dapat dilihat pada Tabel 3 dan4.

Akurasi R-Baux score sebagai nilai prediktor mortalitas pada penelitian ini diperoleh bahwa R-Bauxscore pada cut-off point 58 mempunyai sensitivitas $92,89 \%$, spesifisitas 45,69\%, nilai duga positif $63,10 \%$, dan juga nilai duga negatif 86,54\%. Akurasi BOBI score sebagai nilai prediktor mortalitas pada penelitian ini diperoleh bahwa BOBI score pada cut-off point 3 mempunyai sensitivitas 96,83\%, spesifisitas $47,80 \%$, nilai duga positif $63,10 \%$, dan nilai duga negatif 94,23\%. Akurasi R-Baux dan BOBI score dalam memprediksi mortalitas pada pasien luka bakar dapat dilihat pada Tabel 5.

Nilai kesesuaian R-Baux dan BOBI score sebagai nilai prediktor mortalitas perhitungan IPSS diperoleh koefisien Kappa sebesar 0,50.

Tabel 6 Nilai Kesesuaian R-Baux dan BOBI score sebagai Nilai Prediktor Mortalitas Pada Pasien Luka Bakar

\begin{tabular}{|c|c|c|c|}
\hline \multirow[b]{2}{*}{ R-Baux score } & \multicolumn{3}{|c|}{ BOBI Score } \\
\hline & $\begin{array}{c}\text { Hidup } \\
(<\text { median } 3)\end{array}$ & $\begin{array}{c}\text { Meninggal } \\
(\geq \text { median } 3)\end{array}$ & Total \\
\hline Hidup $(<$ median 58,50$)$ & $151(76,6 \%)$ & $46(23,4 \%)$ & $197(100 \%)$ \\
\hline $\begin{array}{l}\text { Meninggal } \\
(\geq \text { median } 58,50)\end{array}$ & $38(19,3 \%)$ & $159(80,7 \%)$ & $197(100 \%)$ \\
\hline Total & $189(48,0 \%)$ & $205(52,0 \%)$ & $394(100 \%)$ \\
\hline
\end{tabular}


Tabel nilai kesesuaian R-Baux dengan BOBI score sebagai nilai prediktor mortalitas pada pasien luka bakar dapat dilihat pada Tabel 6 .

Uji regresi logistik bivariat dan multivariat dilakukan dengan menggunakan IPSS, diperoleh hasil bahwa variabel usia, TBSA, dan trauma inhalasi berhubungan secara signifikan dengan prediktor mortalitas R-Bauxscore dengan tingkat kepercayaan $\mathrm{p}<0,001$ (tabel tidak ditampilkan) dan tidak ada variabel yang berhubungan secara signifikan dengan prediktor mortalitas BOBI score. Kecuali uji analisis bivariat variabel TBSA yang menunjukkan OR 33,437 dengan tingkat kepercayaan $\mathrm{p}<0,001$ (tabel tidak ditampilkan).

\section{Pembahasan}

Sampel laki-laki yang menderita luka bakar pada periode penelitian ini lebih banyak dibanding dengan perempuan menunjukkan perbandingan 1,98:1. Sampel laki-laki yang meninggal pada penelitian ini sebanyak 61 sampel (58,6\%), lebih banyak dibanding dengan sampel perempuan dengan perbandingan 1,41:1. Hasil ini sama dengan beberapa penelitian sebelumnya bahwa laki-laki lebih sering mengalami luka bakar dan menyebabkan mortalitas dibanding dengan perempuan. ${ }^{8-12}$

Kelompok usia terbanyak adalah kelompok usia $<50$ tahun sebanyak 336 sampel $(85,3 \%)$. Rata-rata usia $28,34 \pm 18,3$ tahun. Usia terbanyak yang meninggal pada penelitian ini adalah kelompok usia $<50$ tahun sebanyak 86sampel $(82,7 \%)$ atau $25,6 \%$ dari populasi dengan rerata usia 30,9 tahun. Hasil ini sesuai dengan penelitian sebelumnya yang menyatakan bahwa usia ratarata pasien luka bakar adalah usia produktif berkisar 25,7 tahun (15-54 tahun). Sample yang meninggal terbanyak berada kelompok usia $<50$ tahun sebanyak 39 sampel atau $17,5 \%$ dari populasi. , $^{8,13,14}$

Penyebab luka bakar paling banyak pada penelitian ini adalah api pada 222 pasien (56,3\%). Penyebab luka bakar yang meninggal terbanyak karena api pada penelitian ini 82 sampel $(78,8 \%)$. Hal ini sesuai dengan penelitian sebelumnya yang menyebutkan penyebab luka bakar terbanyak dan menyatakan kematian adalah api. ${ }^{11,14}$

Total body surface area terbanyak sampel penelitian adalah kelompok TBSA $<20 \%$ sebanyak 178 pasien $(45,2 \%)$ dengan rerata TBSA $26,10 \% \pm 19,55 \%$. Rerata TBSA pasien meninggal adalah $47,9 \%$. Hal ini sesuai dengan penelitian sebelumnya yang menyatakan bahwa rerata TBSA pasien luka bakar terbanyak adalah $\geq 50 \%$. $6,14,15$

Pasien luka bakar yang disertai dengan trauma inhalasi pada penelitian ini adalah 201 sampel (51\%). Pasien luka bakar meninggal yang disertai dengan trauma inhalasi pada penelitian ini sebanyak 96 sampel $(92,3 \%)$ atau $24,4 \%$ dari populasi. Hal ini lebih tinggi dibanding dengan penelitian sebelumnya. ${ }^{4,6,14}$ Penyebabnya multifaktor salah satunya adalah kondisi geografis tempat tinggal dan juga pengetahuan pasien.

Rerata lama rawatan sampel adalah 14,17 $\pm 13,83$ hari. Hal ini tidak jauh berbeda dengan penelitian sebelumnya yang memperoleh rerata lama rawatan adalah 21 hari. ${ }^{11,15}$ Rerata lama rawatan sampel yang meninggal adalah 8,34 hari. Tidak jauh berbeda dari penelitian yang dilaporkan oleh Kumar dkk. yang menyatakan bahwa $82 \%$ kematian setelah kejadian luka bakar terjadi dalam 1 minggu setelah kejadian (2-6 hari). Penelitian oleh Brusselaers dkk. ${ }^{4}$ menyebutkan bahwa median lama rawatan sampel meninggal pada penelitian mereka adalah 5 hari (1-11 hari). ${ }^{14}$

Rerata nilai prediktor mortalitas dengan $R$-Baux score pada seluruh sampel penelitian ini adalah 63,1 dengan median 58,5. Rerata nilai prediktor mortalitas dengan $R$-Baux score pada pasien meninggal adalah 94,5. Nilai prediktor R-Baux score diatas 90 diperoleh mortalitas hingga $50 \%$ dan nilai prediktor di atas 130 diperoleh mortalitas $100 \%$. Rerata nilai prediktor mortalitas dengan BOBI score adalah 2,57 dengan median 3,00 , sedangkan rerata nilai prediktor mortalitas dengan BOBI score pada pasien meninggal adalah 4,9. Nilai prediktor BOBI score di atas 5 diperoleh mortalitas hingga $64,71 \%$ dan nilai prediktor di atas 7 diperoleh mortalitas $100 \%$.

Angka mortalitas pada penelitian ini adalah 26,4\% (104 sampel). Angka mortalitas pada penelitian ini lebih tinggi dibanding dengan penelitian lain di negara maju. ${ }^{5,16}$ Keadaan ini disebabkan oleh tingkat pendidikan dan sosial ekonomi setiap negara berbeda.

Penelitian ini telah membandingkan akurasi $R$-Baux dengan BOBI score sebagai prediktor mortalitas pada pasien luka bakar di RSUP Dr. M. Djamil Padang, dengan melakukan uji sensitivitas, spesifisitas, nilai duga positif, dan nilai duga negatif pada tiap-tiap nilai prediktor ini. Dari penelitian ini didapat akurasi $R$-Baux score pada cut-off point 58 tidak jauh berbeda dengan penelitian lain yang menyatakan bahwa $R$-Baux score memiliki sensitivitas yang tinggi 
untuk memprediksi mortalitas dan baik dipakai sebagai prediktor mortalitas pasien luka bakar., ${ }^{5,17}$

Akurasi BOBI score pada cut-off point median 3 menunjukkan hasil ini tidak jauh berbeda dengan penelitian lain yang menyatakan bahwa BOBI score menunjukkan performa yang baik sebagai prediktor mortalitas pasien luka bakar., ${ }^{70}$ Perbandingan kedua nilai prediktor R-Baux score dengan BOBI score diperoleh bahwa sensitivitas, spesifisitas, dan nilai duga negatif BOBI score lebih baik bila dibanding dengan R-Bauxscore. Belum ada penelitian tentang perbandingan ini sebelumnya.

Dari penelitian ini diperoleh nilai koefisien Kappa sebesar 0,000 dengan kekuatan 0,50. Dengan pengertian uji kesesuaian nilai prediktor $R$-Baux score dan BOBI score menunjukkan bahwa variabel-variabel prediktor $R$-Baux score menunjukkan kesesuaian hasil dengan BOBI score dengan kekuatan sedang. Belum ada penelitian yang mendukung hasil ini sebelumnya. Dari hasil analisis regresi logistik bivariat dan multivariat yang dilakukan terhadap variabelvariabel pada R-Baux score ialah sebagai nilai prediktor mortalitas pasien luka bakar diperoleh hasil bahwa variabel usia, TBSA, dan trauma inhalasi berhubungan secara signifikan dengan prediktor mortalitas $R$-Baux score dengan tingkat kepercayaan $\mathrm{p}<0,001$. Variabel yang paling besar pengaruhnya terhadap nilai prediktor $R$-Baux score adalah variabel TBSA. Sesuai dengan penelitian sebelumnya yang menyatakan mortalitas luka bakar dipengaruhi oleh usia, TBSA, dan trauma inhalasi. ${ }^{4,6,18}$

Dari hasil analisis regresi logistik bivariat dan multivariat yang telah dilakukan terhadap variabel-variabel pada BOBI score sebagai nilai prediktor mortalitas pasien luka bakar diperoleh hasil bahwa tidak ada variabel yang terlibat berhubungan secara signifikan sebagai prediktor mortalitas BOBI score. Kecuali uji analisis bivariat variabel TBSA secara independen menunjukkan OR 33,437 dengan tingkat kepercayaan $\mathrm{p}<0,001$. Hasil ini sesuai dengan penelitian yang dilakukan oleh Blot ${ }^{19}$ menyebutkan dari hasil analisis regresi logistik multivariat yang dilakukannya tidak ada hubungan antara trauma inhalasi, usia dan TBSA dalam memprediksi outcome pasien luka bakar. Menurut para ahli hal ini disebabkan oleh variabel yang terlibat pada sistem skoring ini merupakan estimasi dan dibuat ke dalam sistem skoring yang sederhana.

Simpulan, BOBI score lebih baik sebagai prediktor mortalitas di RSUP Dr.M.Djamil Padang, dibandingkan R-Bauxscore karena menunjukkan akurasi yang lebih baik bila setelah dibanding dengan nilai real. Terdapat kesesuaian hasil antara variabel $R$-Baux dan BOBI score sebagai prediktor mortalitas pasien luka bakar di RSUP Dr. M. Djamil Padang. Variabel usia, TBSA, dan trauma inhalasi menunjukkan pengaruh yang berhubungan terhadap risiko mortalitas pasien luka bakar pada prediktor R-Baux score.

\section{Daftar Pustaka}

1. Moenadjat Y. Luka Bakar: masalah dan tata laksana. Balai Penerbit FKUI. 2009;4:1-38.

2. Yuce Y, Acar HA, Erkal KH, Tuncai E. Can we make an early 'do not resuscitate' decision in severe burn patients?. J Ulus Travma Acil Cerrahi Derg. 2017;23(2):139-43 .

3. Brusselaers N, Monstrey S, Vogelaers D, Hoste E, Blot S. Severe burn injury in europe: a systematic review of the incidence, etiology, morbidity, and mortality. J Critical Care. 2010;14(5):R188.

4. El Mehrat AM, Ghareeb FM, Keshk F, El Sheikh YM, Ibrahim AH. Retrospective study of mortality and causes of death in menofia university burn center. Menoufia Med J. 2014;27(2):290-5.

5. Dokter J, Meijs J, Irma MMH, Oen, Eva BM, Vlies C, dkk. external validation of the revised baux score for the prediction of mortality in patients with acute burn injury. Lippincott Williams \& Wilkins. J Trauma Acute Care Surgery.2014;76(3): 840-5.

6. Brusselaers N, Juhasz I, Erdei I, Monstrey S, Blot S. Evaluation of mortality following severe burns injury in Hungary: external validation of a prediction model developed on belgian burn data. Burns J. 2009;35(7):100914.

7. Karlie J, Wardhana A. External validation of Belgian outcome of burn injury score on burned patient in burn unit cipto mangunkusumo general hospital. New Ropanasuri J Surg. 2017;2(1):90-6.

8. Pujisriyani, Wardana A. Epidemiology of burn injuries in cipto mangunkusumo hospital from 2009 to 2010. Jurnal Plastik Rekonstruksi. 2012;1(5):528-31.

9. Salehi SH, As'adi K, Abbaszadeh KA, Isfeedvajani MS, Khodaei N. Comparison of six outcome prediction models in an adult burn population in a developing country. J Annals Burns Fire Disasters. 2017;30(1):137.

10. Sheppard NN, Gorse SH, Shelley OP, Philp B,Dziewulski P. Prognostic scoring systems in 
burns: a review. Burns J. 2011;37(8):128895.

11. Al Ibran E, Mirza FH, Memon AA, Farooq MZ, Hasan M. Mortality associated with burn injury- a cross sectional study from Karaci, Pakistan. BMC Res Notes. 2013;6:545.

12. Zarei MR, Dianat S, Eslami V, Harirchi I, Boddouhi N, Zandieh A, dkk. Factors associated with mortality in adult hospitalized burn patients in Tehran. Ulus Travma Acil Cerrahi Derg. 2011;17(1):61-5.

13. Dahal P, Ghimire S, Maharjan NK, Man Rai S. Baux's and abbreviated burn severity score for the prediction of mortality in patients with acute burn injury. J College Med Sciences-Nepal. 2015;11(4):24-7.

14. Colohan S. Predicting prognosis in thermal burns with associated inhalational injury: a systematic review of prognostic factors in adult burn victims. J Burn Care Res. 2010; 31(4):529-39.

15. Pantet O, Fouzi M, Brusselaers N, Vemay
A, Berger MM. Comparison of mortality prediction models and validation of SAPS II in critically ill burns patients. Ann Burns Fire Disasters. 2016;29(2):123-9.

16. Kumar S, Ali W, Pandey A, Rathore S. Epidemiology and mortality of burns in the Lucknow region, India-a 5 year study. Burns. 2013;30(4):8-15.

17. Brusselaers N, Agbenorku P, Hoyte-Williams PE. Assessment of mortality prediction models in Ghanaian burn population. Burns J. 2013;39(5):997-1003.

18. El-Helbawy RH, Ghareeb FM. Inhalation injury as a prognostic factor for mortality in burn patients. Ann Burns Fire Disasters. 2011;24(2):82-8.

19. Blot S. Development and validation of a model for prediction of mortality in patients with acute burn injury: the Belgian outcome in burn injury study group. British J Surg. 2009;96(1):111-7. 


\title{
Pengaruh Faktor Risiko terhadap Waktu Timbulnya Efek Samping Kanamisin pada Tuberkulosis Resistan Obat
}

\author{
Martha Ratnawati, ${ }^{1}$ Reviono, ${ }^{1,2}$ Wachid Putranto, ${ }^{3}$ Yusup Subagio Sutanto, ${ }^{1,2}$ Harsini ${ }^{1,2}$ \\ ${ }^{1}$ Bagian Pulmonologi dan Kedokteran Respirasi Fakultas Kedokteran Universitas Sebelas Maret Surakarta, \\ Indonesia, ${ }^{2}$ KSM Paru RSUD Dr. Moewardi Surakarta, ${ }^{3}$ Bagian Penyakit Dalam Sub Bagian Ginjal Hipertensi \\ Fakultas Kedokteran Universitas Sebelas Maret/RSUD Dr. Moewardi Surakarta, Indonesia
}

\begin{abstract}
Abstrak
Kanamisin adalah obat untuk terapi tuberkulosis resistan obat (TB RO) yang menimbulkan efek samping gangguan pendengaran, gangguan fungsi ginjal, dan gangguan elektrolit terutama hipokalemia. Penelitian bertujuan menilai kesintasan waktu timbulnya efek samping dan pengaruh faktor risiko usia, riwayat terapi streptomisin serta berat badan terhadap efek samping akibat pemberian kanamisin pasien TB RO. Penelitian kohort retrospektif dari data rekam medis pasien TB RO dari Januari 2011 sampai April 2017 di RSUD Dr. Moewardi Surakarta. Analisis pengaruh faktor risiko terhadap efek samping menggunakan uji cox regression. Dari 238 pasien didapatkan gangguan pendengaran 143 pasien, gangguan fungsi ginjal 147 pasien, dan hipokalemia 169 pasien. Usia lebih dari 40 tahun hazard ratio (HR) 2,419 (IK: 95\%; 1,716-3,409; $\mathrm{p}=0,000$ ) dan jenis kelamin perempuan HR: 1,549 (IK: 95\%; 1,089-2,202; $\mathrm{p}=0,015$ ) berisiko terjadi gangguan pendengaran. Usia lebih dari 40 tahun HR: 1,892 (IK: 95\%; 1,353-2,646; p= 0,000) dan jenis kelamin perempuan HR: 1,667 (IK: 95\%; 1,179-2,357; p=0,004) berisiko terjadi gangguan fungsi ginjal. Riwayat streptomisin sebelumnya dan indeks massa tubuh (IMT) tidak berisiko timbul efek samping akibat pemberian kanamisin. Pengawasan ketat timbulnya efek samping gangguan pendengaran dan gangguan fungsi ginjal pasien usia lebih dari 40 tahun dan perempuan pada pengobatan TB RO.
\end{abstract}

Kata kunci: Efek samping, gangguan fungsi ginjal, gangguan pendengaran, kanamisin, TB resistan obat

\section{The Effect of Risk Factor on The Onset of Kanamycin's Adverse Events in Drug Resistant Tuberculosis}

\begin{abstract}
Kanamycin is therapy for drug-resistant tuberculosis (TB) which can cause hearing loss, impaired kidney function, and electrolyte disorders especially hypokalemia. The objective of this study was to assess the patient survival and the effects of risk factors such as age, previous history of streptomycin therapy and weight on adverse events due to kanamycin administration in patients with drug resistant TB. A retrospective cohort study was conducted in TB patients by using medical records from January 2011 to April 2017 in Dr. Moewardi hospital Surakarta. Cox regression analysis was used to analyze the relation between risk factors and the adverse events. Of the 238 patients, 143 patients with hearing loss, 147 patients with impaired kidney function, and 169 patients with hypokalemia. Age over 40 and female gender had higher risk for hearing loss and impaired kidney function (HR: 2.419 (95\% CI: 1.716-3.409; $p=0,000$ ) and HR: 1,892 (95\% CI: 1.353-2.646; p=0,000); HR: 1.549 (95\%CI: 1.0892.202; $\mathrm{p}=0,015$ ), and HR: 1.667 (95\% CI: 1.179-2.357; p=0.004)) respectively. History of streptomycin and body mass index (BMI) were not the risk factors of kanamycin's adverse events. Therefore closed monitoring on hearing loss and impaired kidney function is necessary for drug resistantTB patients aged over 40 and female patient.
\end{abstract}

Key words: Adverse events, drug resistant tuberculosis, hearing loss, impaired kidney function, kanamycin

Korespondensi: Martha Ratnawati dr., Bagian Pulmonologi dan Kedokteran Respirasi Fakultas Kedokteran Universitas Sebelas Maret/RSUD Dr. Moewardi Jalan Kol. Soetarto 132 Surakarta, Email martha.bumiwana@gmail.com 


\section{Pendahuluan}

Obat antituberkulosis atau OAT merupakan komponen yang terpenting dalam pengobatan tuberkulosis (TB). Perkembangan selanjutnya ditemukan kuman TB resistan obat (RO). World Health Organization (WHO) merekomendasikan obat suntik lini kedua untuk pengelolaan TB RO, di antaranya adalah golongan aminoglikosida terdiri dari streptomisin, kanamisin, amikasin, dan juga golongan polipeptida kapreomisin. Kanamisin dapat menimbulkan efek samping yang berat, yaitu ototoksik, gangguan elektrolit (hipokalemia, hipomagnesemia, hipokalsemia), dan gangguan fungsi ginjal (nefrotoksik). ${ }^{1-3}$

Ototoksik oleh karena pemberian kanamisin dapat menimbulkan gangguan pendengaran (kokleotoksik) serta gangguan keseimbangan (vestibulotoksik). Kanamisin lebih dominan menyebabkan efek samping kokleotoksik berupa gangguan pendengaran dan atau tinnitus., ${ }^{4,5}$ Faktor risiko ototoksisitas adalah pemberian terapi $>7$ hari, riwayat pemakaian aminoglikosida sebelumnya, dosis tinggi harian, peningkatan kadar obat dalam serum, paparan suara bising, pemakaian usia sangat muda/tua dan mutasi deoxyribonucleic acid (DNA) mitokondria. ${ }^{6}$

Efek samping dari kanamisin pada ginjal merupakan kejadian yang sering. Nefrotoksik karena pemberian kanamisin diakibatkan oleh toksisitas di tubulus ginjal, penurunan filtrasi glomerulus dan penurunan aliran darah ke ginjal yang akhirnya menimbulkan gangguan fungsi ginjal ditandai nonoliguri, poliuri hipoosmotik serta peningkatan ureum dan kreatinin serum.7,8 Faktor risiko nefrotoksisitas di antaranya usia tua, penurunan fungsi ginjal sebelumnya, kehamilan, dehidrasi, dan kurang natrium. ${ }^{7}$ Kanamisin terakumulasi di tubulus proksimal dalam jangka lama juga menyebabkan gangguan keseimbangan elektrolit terutama hipokalemia. Faktor risiko gangguan elektrolit pasien TB RO meliputi kumulatif dosis, berat badan rendah, dan penggunaan kapreomisin. ${ }^{7,8}$

Penelitian bertujuan menganalisis kesintasan timbulnya efek samping kanamisin kepada pasien TB RO, yaitu gangguan pendengaran, gangguan fungsi ginjal dan hipokalemia. Analisis faktor risiko usia, riwayat terapi streptomisin sebelumnya, dan berat badan terhadap efek samping kanamisin pada pengobatan TB RO.

\section{Metode}

Penelitian ini merupakan penelitian kohort retrospektif dari data rekam medis pasien TB RO Januari 2011-April 2017 di RSUD Dr. Moewardi Surakarta. Teknik pengambilan sampel dengan total sampling yaitu semua populasi pasien TB RO dari bulan Januari 2011-April 2017. Kriteria inklusi adalah pasien TB RO dari bulan Januari 2011-April 2017 diterapi kanamisin pada rejimen TB RO. Kriteria eksklusi adalah catatan rekam medis pasien tidak ada/tidak lengkap, riwayat pemakaian kanamisin selama $\geq 1$ bulan dalam 6 bulan terakhir, gangguan pendengaran tipe sensory neural hearing loss (SNHL) saat base line, pasien meninggal atau tidak melanjutkan pengobatan (putus berobat, pindah) sebelum timbul efek samping dalam masa penelitian 8 bulan, pemakaian obat ototoksik (sisplatin, karboplatin, furosemid, bumetanid, hidrokodon, metadon, salisilat, kinin, klorokuin, hidroklorokuin, eritromisin, azitromisin, deferoksamin, dan vankomisin), pemakaian obat nefrotoksik (NSAIDs, golongan statin, amfetamin, fenofibrat, amfoterisin B, antivirus (asiklovir, sidofovir, indinavir, foskamet, tenofovir), pentamidin, diuretik, vankomisin, siklosporin, dan obat kemoterapi (sisplatin, ifosfamide, plicamycin, 5-fluorouracil, cytarabine, 6-thioguanine, metrotreksat), serta yodium (zat kontras).

Penelitian ini mencatat waktu timbulnya efek samping, yaitu gangguan pendengaran, gangguan fungsi ginjal, dan hipokalemia pasien TB RO dengan terapi kanamisin. Timbulnya efek samping dihubungkan dengan faktor risiko berdasar usia, riwayat pengobatan streptomisin sebelumnya, dan berat badan (menggunakan indeks massa tubuh (IMT)). Efek samping gangguan pendengaran tipe SNHL dengan hasil audiometri $\geq 26 \mathrm{~dB}$. Gangguan fungsi ginjal didapatkan kreatinin serum meningkat $\geq 0,3 \mathrm{mg} /$ dL (1,5-2 kali lipat) dari baseline. Hipokalemia dikategorikan dengan nilai kalium $<3,5 \mathrm{meq} / \mathrm{L}$. Data dasar diolah secara deskriptif. Angka kesintasan dan median kesintasan efek samping kanamisin dengan kaplan meier dan analisis cox regression untuk menilai faktor risiko (usia, berat badan, dan riwayat streptomisin) yang berpengaruh terhadap timbulnya efek samping. Semua uji statistik menggunakan nilai batas kepercayaan 95\% (95\% Indeks Kepercayaan) atau nilai batas kemaknaan $\mathrm{p}<0,05$.

\section{Hasil}

Penelitian dilakukan di ruang rekam medis RSUD Dr. Moewardi Surakarta. Pemilihan tempat 
Tabel 1 Karakteristik Dasar Subjek Penelitian

\begin{tabular}{|c|c|c|}
\hline Karakteristik & $\begin{array}{c}\text { Jumlah } \\
(n=238)\end{array}$ & $\begin{array}{c}\text { Persentase } \\
(\%)\end{array}$ \\
\hline \multicolumn{3}{|l|}{ Jenis kelamin } \\
\hline Laki-laki & 105 & 44,1 \\
\hline Perempuan & 133 & 55,9 \\
\hline \multicolumn{3}{|l|}{ Usia (tahun) } \\
\hline$>59$ & 8 & 3,4 \\
\hline$\leq 59$ & 230 & 96,6 \\
\hline \multicolumn{3}{|l|}{ Usia (tahun) } \\
\hline$>59$ & 8 & 3,4 \\
\hline $40-59$ & 137 & 57,5 \\
\hline$<40$ & 93 & 39,1 \\
\hline \multicolumn{3}{|l|}{$\mathrm{IMT}^{*}\left(\mathrm{kgBB} / \mathrm{m}^{2}\right)$} \\
\hline$<18,5$ & 153 & 64,3 \\
\hline$\geq 18,5$ & 85 & 35,7 \\
\hline \multicolumn{3}{|c|}{ Riwayat streptomisin } \\
\hline Ya & 119 & 50,0 \\
\hline Tidak & 119 & 50,0 \\
\hline
\end{tabular}

*: Indeks massa tubuh

berdasar atas pertimbangan pencatatan rekam medis pasien TB RO. Hasil pencatatan rekam medis pasien TB RO didapatkan sebanyak 450 pasien TB RO, yang digunakan dalam penelitian 238 pasien TB RO. Hasil karakteristik dasar subjek penelitian pasien TB RO (Tabel 1).

Pasien TB RO berdasar atas Tabel 1 diketahui dari 238 pasien sebagian besar perempuan, yaitu 133 pasien $(55,9 \%)$. Usia pasien TB RO mayoritas $<40$ tahun, yaitu 93 pasien $(39,1 \%)$.
Indeks massa tubuh (IMT) mayoritas pasien TB R0 dalam kategori gizi kurang $\left(<18,5 \mathrm{kgBB} / \mathrm{m}^{2}\right)$, yaitu ada 153 pasien $(64,3 \%)$. Riwayat pasien mendapat obat suntik streptomisin dan tidak mendapat streptomisin masing-masing ada 119 pasien $(50 \%)$.

Efek samping dari gangguan pendengaran, gangguan fungsi ginjal dan hipokalemia pada pemberian kanamisin pasien TB RO dapat dilihat pada tabel satu. Pasien TB RO dari 238 orang terjadi gangguan pendengaran sebesar 143 pasien dan 23 pasien $(9,7 \%)$ terjadi gangguan pendengaran di bulan pertama. Angka kesintasan dari efek samping gangguan pendengaran adalah 39,9\% dengan median kesintasan 6 bulan. Gangguan fungsi ginjal didapatkan pada 147 pasien dan 30 pasien $(12,6 \%)$ yang terjadi pada bulan pertama. Angka kesintasan pasien dengan efek samping gangguan fungsi ginjal adalah 38,2\% dan median kesintasan 6 bulan. Hipokalemia didapatkan pada 169 pasien dan 64 pasien $(26,9 \%)$ terjadi di bulan pertama. Angka kesintasan pasien dari efek samping hipokalemia adalah 29,0\% dengan median kesintasan 3 bulan. Kurva kaplan meier pasien TB RO dengan efek samping gangguan pendengaran, gangguan fungsi ginjal dan hipokalemia (Gambar).

Pasien perempuan dapat berisiko mengalami gangguan pendengaran 1,549 kali lebih sering dibanding dengan laki-laki (IK 95\%; 1,0892,202). Usia $>59$ tahun memiliki risiko 4,865 kali lebih sering terjadi gangguan pendengaran dibanding dengan usia <40 tahun (IK 95\%; 2,294-10,317). Hasil analisis faktor risiko gangguan pada pendengaran dengan uji cox regression (Tabel 2).

Perempuan berisiko terjadi gangguan fungsi ginjal 1,667 kali lebih sering dibanding laki-laki

Tabel 2 Variabel yang Berpengaruh terhadap Gangguan Pendengaran dengan Analisis Cox Regression

\begin{tabular}{lcccc}
\hline & Variabel & HR & IK 95\% & p \\
\hline Jenis kelamin & Laki-laki & 1 & & 0,015 \\
Usia (tahun) & Perempuan & 1,549 & $1,089-2,202$ & 0,000 \\
& $<40$ & 1 & & 0,000 \\
IMT* $\left.^{*} \mathrm{kgBB} / \mathrm{m}^{2}\right)$ & $40-59$ & 2,419 & $1,716-3,409$ & 0,928 \\
& $>59$ & 4,865 & $2,294-10,317$ & $0,695-1,394$ \\
Riwayat streptomisin & $\geq 18,5$ & 1 & & 0,596 \\
\hline
\end{tabular}

*: Indeks massa tubuh 


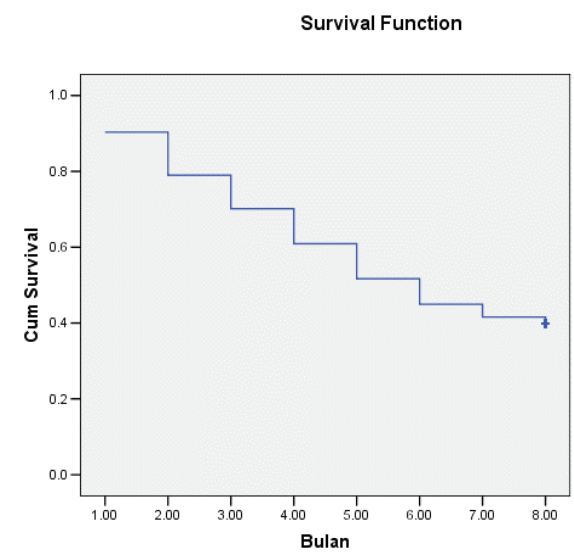

A. Gangguan Fungsi Ginjal

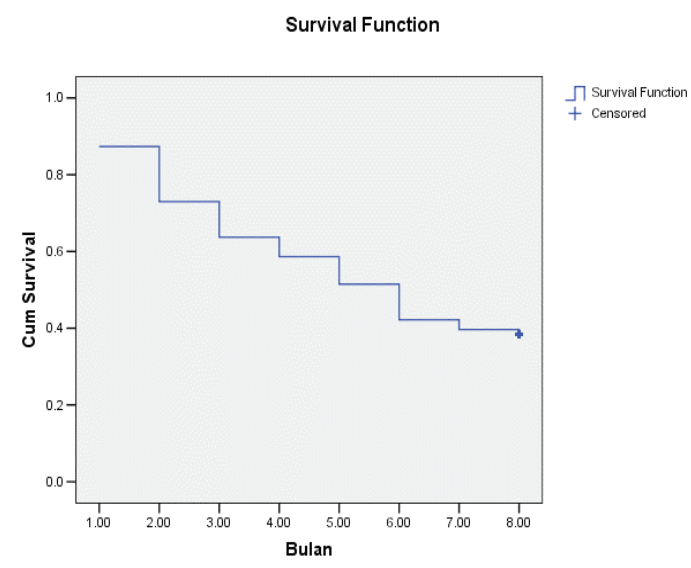

B. Gangguan Pendengaran

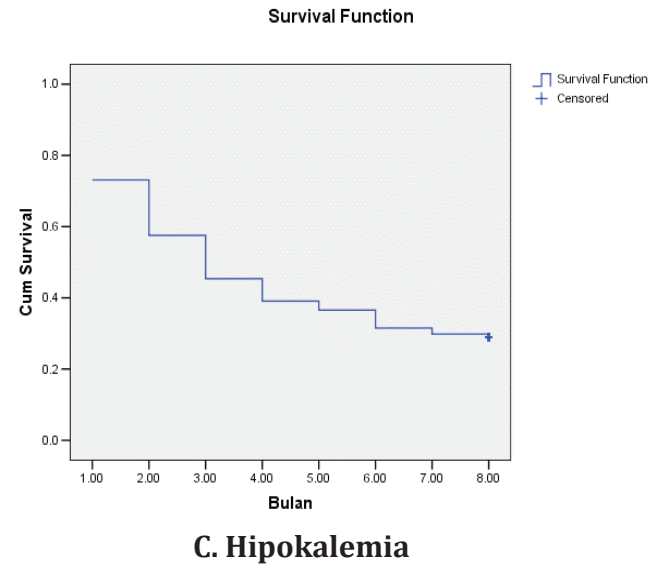

Gambar Kurva Kaplan Meier Efek Samping Kanamisin Pasien TB RO

Tabel 3 Variabel yang Berpengaruh terhadap Gangguan Fungsi Ginjal dengan Analisis Cox Regression

\begin{tabular}{llccc}
\hline & \multicolumn{1}{c}{ Variabel } & HR & IK 95\% & p \\
\hline Jenis kelamin & Laki-laki & 1 & & \\
Usia (tahun) & Perempuan & 1,667 & $1,179-2,357$ & 0,004 \\
& $<40$ & 1 & & \\
& $40-59$ & 1,892 & $1,353-2,646$ & 0,000 \\
IMT* $^{*}\left(\mathrm{kgBB} / \mathrm{m}^{2}\right)$ & $>59$ & 3,810 & $1,793-8,097$ & 0,001 \\
& $\geq 18,5$ & 1 & & \\
Riwayat streptomisin & $<18,5$ & 0,885 & $0,628-1,248$ & 0,487 \\
& Tidak ada & 1 & & \\
& Ada & 0,984 & $0,685-1,329$ & 0,782 \\
\hline
\end{tabular}

*: Indeks massa tubuh 